\title{
LAYERED TEMPORALITIES - BETWEEN MODERNISM AND POSTMODERNISM IN JHUMPA LAHIRI'S THE LOWLAND
}

\author{
Adriana-Elena Stoican \\ Bucharest University of Economic Studies, Bucharest, Romania
}

\begin{abstract}
The discussion approaches Jhumpa Lahiri's novel The Lowland, aiming to trace the author's positioning in relation to modern and postmodern assumptions. The argument follows the main character's (Gauri) transnational trajectory, as she crosses frontiers in a journey that also spans large temporal dimensions. Gauri's unconventional choices are to be interpreted in relation with her permanent interest in the nature of time that is also a part of her doctoral research in philosophy. Gauri's professional goals and her personal destiny appear strongly conditioned by the political context of her pre-emigration days, i.e. the Naxalite movement. All the above suggest that The Lowland can be read as a novel with an implied message about the grand narrative of history in relation to time perception and the possibility of (female) identity formation. Whether Lahiri's approach to these themes echoes a predominantly (post)modern outlook is the focus of the present analysis.
\end{abstract}

Keywords: Circular time, Egoism, Linear time, Modernity, (Post)modernism

\section{Article history:}

Submitted: 1 September 2020

Reviewed: 29 September 2020

Revised: 4 November 2020

Accepted: 27 November 2020

Published: 21 December 2020

Copyright (c) 2020 Adriana-Elena Stoican

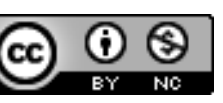

This open access article is published and distributed under a CC BY-NC 4.0 International License which permits non-commercial use, distribution, and reproduction in any medium, provided the original author and source are credited. Permissions beyond the scope of this license may be available at adriana.stoican@rei.ase.ro. If you want to use the work commercially, you must first get the authors' permission.

Citation: Stoican, A-E. (2020). Layered Temporalities - Between Modernism and Postmodernism - in Jhumpa Lahiri's The Lowland. English Studies at NBU, 6(2), 249-264. https://doi.org/10.33919/esnbu.20.2.5

Adriana-Elena Stoican received her Ph.D. in Literary and Cultural Studies from the University of Bucharest, Romania. She currently teaches English for Business Communication at the Bucharest University of Economic Studies. Her research interests include Indian diasporic fiction in English, comparative literature, South Asian American literature, postcolonial studies.

E-mail: adriana.stoican@rei.ase.ro

https://orcid.org/0000-0001-9791-3540 


\section{Jhumpa Lahiri: Writing Across Literary Trends}

Jhumpa Lahiri's fictional work ${ }^{1}$ presents processes of cultural negotiation experienced by first and second-generation Bengali characters, predominantly women, but also men. The author highlights instances of cultural clashes and transnational migration, also tracing manners in which her characters attempt to build meaningful dialogues across cultural difference. Given these coordinates, Lahiri's work has been analyzed as ethnic American literature (Brada-Williams, 2004; Iyer, 2009; Madhuparna, 2006), postmodern literature (Anwar, 2015; James, 2015; Song, 2007) postcolonial literature (Bandyopadhyay 2009), American literature (Caesar, 2005; Caesar, 2007; Chetty, 2006), diasporic literature (Banerjee, 2010; Bhalla, 2008; Brians, 2003; Kemper, 2011; Munos, 2010; Raj \& Jose, 2014; Saha, 2009;), from a gender studies perspective (Bran, 2014; Ranasinha, 2016; Williams Anh, 2007) and from a political angle (Samanta, 2014). Consequently, most of these interpretations have mainly addressed the author's thematic universe, predominantly linking Lahiri with postmodernism, postcolonialism and feminism. However, several critical voices have also recorded Lahiri's formal leanings to realism, highlighting her 'narrative propensity for realism' (Zhang, 2012, p. 214), her 'composed, unadorned, frugal narrative style' (James, 2015, p. 52), 'middle class realism and ... miniaturist prose', (Ranasinha, 2016, p. 35) or her 'patient, polished realism' (Seshagiri, 2016, para.1). There seems to be a sense of agreement with respect to Lahiri's multiple connections with various trends, since her narrative style can be linked to realism, while her thematic focus corresponds to both modernist and postmodernist concerns.

\section{Asian American literature: from realism to postmodernism}

In a very interesting study of Asian American literature, Yifan Zhang (2012) discusses the evolution of this field from an initial reliance on realism to its subsequent adherence to modernism and postmodernism. The first stage - the survival fiction -

\footnotetext{
${ }^{1}$ Her first collection of short stories, Interpreter of Maladies (1999), presents interactions between Indian and American characters placed in either Indian or American settings (the East Coast). Her first novel The Namesake (2003), presents the evolution of a Bengali immigrant family, focusing on different strategies of navigating multiple traditions. Her last collection of short stories, Unaccustomed Earth (2008) foregrounds the second-generation characters' effort to make sense of their cultural inheritance. A second novel, The Lowland (2013) presents the transnational dispersion of a Bengali family across physical and temporal borders. Her last book, In Other Words represents a shift to autobiography and depicts the writer's relocation to Rome where she studies Italian in order to write this book in a new language.
} 
placed before $1965^{2}$, employed realism in order to illustrate the minorities' concerns to assimilate and conquer America by representing ethnic traditions through realistic details (pp. 27-28). A second stage, the transformation fiction, maintained the realist forms, with a slightly altered thematic focus. Its protagonists are assimilated AsianAmericans or members of model minorities whose dilemma is the negotiation of different identity coordinates (Asian and American). The resulting sense of tension is the focus of the transformation fiction that announces the intrusion of modernism into Asian American fiction, through its "interference of individuality (Zhang, 2012, p. 28). The third phase of Asian American literature is represented by the 'contradiction fiction' (p. 29), which deepens the conflict between individuals and communities, to the point of celebrating individuality at the expense of ethnicity' (p. 29). Contradiction fiction is associated with the "transnational, transpacific and diasporic" Asian American itineraries (Sumida qtd. in Zhang p. 163). Interestingly, Zhang warns that the term 'contradiction' is used here to signify "contradictions in the mode of cognition and the form of narrative" (pp.164). In other words, contradiction fiction is to be situated and interpreted at the crossroad between two major coordinates: ideological frameworks (postmodern America and neocolonial Asia) and narrative conventions (realism and modernism) (Zhang pp. 164-165). Zhang does not associate the contradiction fiction with a postmodern narrative style, but rather with postmodernism as a post-structural episteme that foregrounds the "alternative history of Asian America" (Zhang pp. 14). The deconstructive implications of postmodernism imply the contestation of (Western) grand narratives and the exploration of multiculturalism as a possibility to claim respect for cultural difference. Following Zhang's challenging insight, the present argument sets out to unravel the extent to which The Lowland innovatively blends postmodern and modern assumptions within a predominantly realistic narrative framework.

\section{Modernity, modernism, postmodernism linear and circular time/history}

Modernism is considered a reaction to 'the malady of modernity', an 'antitechnological critique of Western civilization', characterized by intense mechanization, industrialization and urbanization (Nabholz, 2007, pp. 37-38). Modernity is also associated with the Enlightenment views of history as linear progress/advancement

\footnotetext{
${ }^{2}$ In 1965, the USA immigration laws became more permissive, as stipulated by the Hart-Celler Act, fact that generated an increase of the immigrant flows.
} 
(Williams Blakeney, 2002, p. 7) history as evolution towards a goal, i.e. teleological view of history (O'Malley, 2014, p. 12). Therefore, the belief in progress sustained by modernity generates the conception of linear time, (Nabholz, 2007, p. 99), associated with the idea of development, movement and technological changes. Modern artists embraced the notion of non-progressive time, claiming that history moves in circles rather than chronologically. Given that the circle is a symbol of infinite, endless structures (Small, 2010, p. 115), cyclic/circular patterns were perceived as orderly configurations, capable of providing freedom from the tyranny of progressive modernity. The repetitive nature inherent in cyclic patterns was associated with a sense of transcendence, permanence and stability (Williams Blakeney, 2002, p. 13) that undermined the linear outlook of history as progress (Nabholz, 2007, p. 83).

Interestingly, the modernists' embrace of a circular view of history and their fascination with Eastern art reveals a possible intersection between Western and Oriental notions of temporality. Although the present paper does not aim to homogenize Oriental conceptions of time by defining them as exclusively circular, it works with this premise only in so far as it refers to Western modernism's attraction to certain Eastern models of time that promote circularity. The complexity of Eastern temporalities is to be further discussed in a different paper. From a Zen Buddhist and Taoist perspective, life is defined as formless flux that fuses the past and the future into the present moment. This vision totally contradicts the Western dichotomous understanding of the world that relies on the distinct coordinates of space and linear time (Nabholz, 2007, p. 91). Similarly, the Hindu mythical tradition, conceives the structure of the world as an alternation of 'cosmic cycles - eons following each other in the endlessness of time' (Zimmer, 1990, p. 130).

The postmodern conceptualization of history entails an embrace of time as Kairos (Olsen, 1990, p.66), the opposite of Cronos, i.e. the time of causality and continuity. The postmodern fracturing of temporality results in a peculiar way of treating history, by reintegrating it into a continuous present and undermining the idea of historical continuity. Thus, history acquires the status of an arbitrary, invented narrative, a form of fiction that extracts its substance from an existential present. By rejecting metanarratives and historical memory, postmodernism transcends cronos and provides a refuge into Kairos, away from the traumatic forces of the historical past. Having discussed 
the modern and postmodern conceptions of time and history, the paper will continue with an analysis of the The Lowland, aiming to grasp the author's position regarding time, history and change as reflected in Gauri's profile.

\section{Between linear and circular time: the impossible choice?}

The plot of the novel is initially placed in Calcutta, around the late 1940s, when two brothers (Subhash and Udayan) are born. In the late 1960s, Subhash applies for a PhD in the United States, while Udayan becomes attracted by the Naxalbari movement. This leftist political manifestation was ignited by the West Bengal peasant uprising against the landlords' feudal ownership and taxation policies (Mustafi, 2012, para. 2). Brutally repressed by the police, the insurgency triggered a chain of violent confrontations between the guerrilla revolutionaries and the Indian state. (Udayan is eventually executed by the police, while his parents and wife, Gauri, witness the whole scene). After his brother's death, Subhash temporarily returns to India and finds out that Gauri is pregnant. Wishing to save her from isolating widowhood, Subhash proposes to Gauri and she accepts to be his wife. In America, Gauri gives birth to a girl, Bela, but her marriage with Subhash does not work. Gauri eventually chooses an academic career, secretly leaving for California, where she gets a teaching position. The next part of the paper aims to correlate Gauri's academic interest in Schopenhauer, Nietzsche and Hegel with her personal redefinition beyond conventional female roles.

\section{Academia: seeking a refuge}

During her pregnancy, Gauri surreptitiously attends undergraduate courses in the philosophy department, where she discovers Heraclitus, Parmenides, Plato, Aristotle (Lahiri, 2013, p. 104). In the summer before giving birth to Bela, Gauri spends her time in the library, enlarging her knowledge of Western philosophy. After she gives birth to Bela, Gauri keeps going to the library where she strives to configure a comprehensive philosophy of time:

She saw time; now she sought to understand it. She filled notebooks with her questions, observations. Did it exist independently, in the physical world, or in the mind's apprehension? Was it perceived only by humans? What caused certain moments to swell up like hours, certain years to boil down to a number of days? (Lahiri, 2013, p. 118)

The character's constant interest in this topic seems to spring from a personal motivation to understand the flow of time in relation to change and objective/subjective 
perception. I argue that Gauri's persistent focus on this conceptual category has to be discussed in relation to her tragic intersection with history. In Otto Weiss' class, Gauri listens to lectures on Schopenhauer's connections with Hindu philosophy; hence, she feels inspired to write a paper that compares Nietzsche's and Schopenhauer's philosophies of circular time (Lahiri, 2013, p. 130). When Bela turns twelve, Gauri abandons her family and moves to California where she teaches philosophy to undergraduate students. Interestingly, Gauri specializes in German Idealism and the philosophy of the Frankfurt School; her major publications involve analyses of Hegel, Horkheimer and Schopenhauer.

Gauri's philosophical interests reveal important clues for understanding her ardent impetus for disruptive transformations. Running away from the Nazi domination, the members of the Frankfurt School introduced Marxism and Critical Theory in the West. Their discourse represented a socialist humanistic stance, that criticized commodity fetishism; it promoted "progressive possibilities for individual development" (Bronner, 2011, p. 49), individual autonomy (Bottomore, 2003, p.41) and liberation from"the dominion of money, commodification and class hierarchies (Cooper, 2006, p.81). Reacting against phenomenology and positivism, the thinkers of the Frankfurt School contested the idea of fixed essences through a 'negative dialectics' (Bronner, 2011, p. 4) that anticipated poststructuralist assumptions. As well as the members of the Frankfurt School, Gauri is a displaced intellectual, also affected by the turbulent forces of history. Moreover, as a former sympathizer of the Naxalites' "revolutionary humanism" (Banerjee, 1984, p. iii), Gauri believed in the leftist utopia of social equality. Sadly, the movement failed to deliver its humanistic promise, as suggested by its eventual reliance on "criminal actions" (Jawaid, 1979, p. 46) that caused loss of innocent lives. By exploring the leftist philosophy of the Frankfurt School, Gauri may attempt to retrieve the (wasted) humanistic potential of the Naxalite ideal and atone for her own involvement in a failed revolution. More specifically, Gauri seems attracted by the humanistic project of individual redefinition through an "exercise of freedom" (Norman, 2004, p.6) that emphasizes "human agency, subjectivity and individuality" (Cooper, 2006, p.80). To this end, the deconstructive philosophies of the Frankfurt School provide Gauri the necessary tools to dismantle her identity coordinates that connect her with a disturbing past. (As discussed in a different paper, [Stoican, 2018] Gauri performs a chain of transgressions, 
perfectly aligned with anti-foundational assumptions: she gradually gives up widowhood, wifehood and ultimately motherhood). At the same time, these philosophies also help her search for a postmodern conception of history and access Kairos, in order to transcend the traumatic dimensions of the past.

Gauri's feminist take on Hegel signals her impulse to undermine conventional gender prescriptions, by adopting an autonomous and rational perspective that makes her feel in control. According to Hegel, history represents the succession of those events that contribute to the actualization of freedom, which is an essentially human impulse (Dudley, 2009). Therefore, history is a 'linear and developmental concept' (Konzett, 2002, p. 11), a coordinate that facilitates Gauri's independent transformation while in America: 'Hegel understands history precisely as the passage from determination by given, external, i.e., natural forces, to free self-determination' (Maker, 2009, p. 20). Therefore, Gauri's focus on Hegel can be correlated with her humanistic approach to identity and change. Although she realizes that her radical path to redefinition involves hurting others, Gauri privileges selfhood as the only possibility of freedom:

With her own hand she'd painted herself into a corner, and then out of the picture altogether ... Within her was the guilt and the adrenaline unleashed by what she'd done, the sheer exhaustion of effort. As if, in order to escape Rhode Island, she'd walked every step of the way. She'd done it, the worst thing that she could think of doing. (Lahiri, 2013, p. 180)

As she steps out of traditional gender roles, Gauri clearly follows individualist and feminist lines of development, along humanistic values of liberation . Her refuge in the world of academia illustrates the triumph of her passion for learning, at the expense of attachment to family. This suggests that the path to her self-transformation implies a radical understanding of humanism as a "person-centered approach" (Cooper, 2006, p.86), that makes Gauri overlook her responsibility to others. If one tries to translate Gauri's identity project in terms of her research interests, one can say that Gauri blends a linear conception of history as an intersection of freedom and reason (Hegel) with an anti-foundational approach to identity and history (Frankfurt School). Hence, linearity is correlated with the intended project of autonomous self-development beyond attachments of any kind, while the deconstructive aspect facilitates Gauri's redefinition in radical terms. Considering her unconventional perspective, the paper continues by discussing Gauri's conception of time and history. The argument will present 
Schopenhauer's and Nietzsche's views on time as well their connections with Eastern philosophy, aiming to establish Gauri's own synthesis.

As illustrated by her reflections, Gauri defines herself as a holder of a chronological conception of time. Her mental representation entails a two-dimensional temporal axis with the past situated on the right and the future on the left side. Interestingly, this linear configuration does not contain the present moment, whose unfolding sidesteps Gauri's perception. The character's inability to process the present moment appears to 'disturb' the precise geometrical scheme of her temporal horizons:

She had been born with a map of time in her mind ... Her strongest image was always of time, both past and future; it was an immediate horizon, at once orienting and containing her ... To the right was the recent past: the year she'd met Udayan, and before that, all the years she'd lived without knowing him. ... To the left was the future, the place where her death, unknown but certain, was an end point ... Only the present moment, lacking any perspective, eluded her grasp. It was like a blind spot, just over her shoulder. A hole in her vision. But the future was visible, unspooling incrementally. (Lahiri, 2013, p. 88)

An element that further disrupts a neat representation of linear time is the idea of a map, which denotes Gauri's spatial understanding of time. This peculiar association of space and time in the character's understanding of linear time, reveals the inconclusiveness of her perceptions. More specifically, a Western (linear) conception of time relies on the assumption that time and space are different coordinates, while a circular notion of time dissolves these dimensions into a pure present (Nabholz, 2007, p. 94). Therefore, Gauri's map of linear time strangely blends a chronological, sequential view with a nonlinear conception that considers space 'an integral part of the experience of time' (Nabholz, 2007, p. 94). In other words, this spatial configuration of time alludes to Eastern conceptual traces that overlap with Gauri's option for a progressive view. At the same time, her inability to make sense of the present moment also indicates the incompleteness of a circular vision of time, that disintegrates past and future into an eternal present (Nabholz, 2007, p. 95). Gauri's struggle to access the present moment reflects her incapacity to build up a redemptive vision of history that relies on Kairos. Considering Gauri's protean vision of temporality, the next section aims to establish whether her temporal orientation eventually privileges a progressive or cyclical approach to time/history. To this end, the argument connects the character's interest in the philosophical perspectives on time formulated by Schopenhauer and Nietzsche, two of the references invoked in her research interests. 
Gauri's split vision of time can be understood if one links it with Schopenhauer's distinction between the world as Representation/Vorstellung and world as Will/Wille. The layer of Vorstellung is the world as appearance, a dimension governed by space and time, which stand for principles of individuation. Consequently, in the world as representation, people believe that they are radically different from others, therefore separated by their individuality. On the other hand, the world as Will, i.e. the world as thing in itself, represents a higher level of perception, by means of which people understand that individuation is a mere phenomenon, rather than ultimate part of reality (Schopenhauer, 1969). According to Schopenhauer, the second view of the world implies the realization that individuals are not separated, but part of the same universe. At this point, one can establish the connection between Schopenhauer's classification and the Indian philosophy of Maya versus the ideal of Unity. As Janaway clearly explains, Schopenhauer's world as representation corresponds to the Indian conception of Maya, equated with the world of mirage, deception, illusion of plurality. At the same time, the world as thing in itself can be arrived at by means of a transcendent vision that transgresses Vorstellung and comprehends the supreme truth of the absolute unity of all beings, tat tvam asi: this art thou (p. 101). The transition from the world of Maya to the world of the will, implies the passage to a higher level of perception, where the categories of individuation dissolve in a perennial condition. In other words, if one transcends Maya, one can reach the timeless dimension of an eternal present, specific to the Oriental conceptions of time.

As Gauri makes the radical decision to abandon her family, she operates within the parameters of Maya, being animated by egoism: 'every individual, completely vanishing and reduced to nothing in a boundless world, nevertheless makes himself the centre of the world, and considers his own existence and well-being before everything else' (Schopenhauer, 1969, W1, p. 332). As a carrier of individualistic values, Gauri clings to a progressive, sequential notion of time. This conception seems to provide space for her autonomous transformation, placed in a future dimension, away from familiar contexts. Seen from this angle, her inability to perceive the present moment marks her impossibility to transcend Maya and therefore heal. At the same time, Bela's nonchronological perception of time, as filtered by Gauri, is associated with the Bengali cultural core and contrasted with Gauri's linear perspective: 
It was the English word she [Bela] used. It was in English that the past was unilateral; in Bengali, the word for yesterday, kal, was also the word for tomorrow. In Bengali one needed an adjective, or relied on the tense of a verb, to distinguish what had already happened from what would be.

Time flowed for Bela in the opposite direction. The day after yesterday, she sometimes said. ...

Bela's yesterday was a receptacle for anything her mind stored. Any experience or impression that had come before. Her memory was brief, its contents limited. Dispersed but still afloat, lacking chronology, randomly rearranged. (Lahiri, 2013, p. 117)

Bela's perception of time reflects the child's innocent perspective, that overlaps with Eastern notions of circular time that also appealed to Western modernism. However, given Bela's little exposure to the Indian culture, we may assume that is Gauri's interpretation that explicitly connects Bela's vision of time with the Indian world. At this point, the opposition between Gauri and her daughter becomes apparent, given that they seem to carry different conceptions of time and history. On the one hand we have Bela, unaware of the chronological flow of time, therefore oblivious to the effects of history. On the other hand, we have Gauri, traumatized by her past and unable to complete her linear chronology by accessing the present moment. I will rely on Robin Small's (2010) interpretation of Nietzsche's understanding of time to provide additional tools for deciphering Gauri's struggle with the impact of history.

Holder of an anti-foundationalist outlook, Nietzsche considers that the world relies on an endless process of transformation, at odds with the illusion of permanence and stability. A supporter of the principle of absolute becoming, Nietzsche argues that the world is set in motion by an everlasting process of change, i.e. becoming, conceptualized as a 'continual process of conflict between opposite qualities' (Small, 2010, p. 11). The idea of ceaseless transformation is linked to a circular conception of time - 'the eternal recurrence' - whose cycles are determined by the 'alternating dominance of opposing forces' (Small, 2010, p. 89). The idea of contradiction within layers of temporality is expressed by the metaphor of lanes (the past and the future) and the gateway, i.e. the (present) Moment situated between the lanes (Small, 2010, p. 79). Interestingly, by advancing the idea of an unhinged gateway, Nietzsche conceptualizes the Moment as a point of intersection, not separation between the past and the present. Thus, the openness of the Gateway 'allows for a direct confrontation between past and future in the moment: they come together and meet face to face, not by proxy' (Small, 2010, p. 96). 
Moreover, as he posits the circular nature of time, Nietzsche transcends the very idea of contradiction between past and future within the present moment, implying that the two temporal lines dissolve into the present moment: 'What does this say about the conflict between past and future? There can be none on this hypothesis, because there is no difference between past and future. If they seem to be in conflict at the 'moment', that must be an illusion' (Small, 2010, p. 114). Considering these reflections, I would argue that Gauri's inability to access the present moment also illustrates her incapacity to reconcile her past with her present, and filter history through a present grid. In other words, the traumatic traces of Gauri's past, ${ }^{3}$ cannot be set into direct confrontation. This suggests that these two dimensions of temporality cannot reach a point of resolution from the perspective of a different Gauri, one transformed by the time that has passed since her emigration. At the same time, her linear perspective on time is set in opposition to Bela's, in order to suggest Gauri's yearning for a childlike vision, beyond chronological binarisms. At this point, Small's argument is highly illustrative as it clarifies Nietzsche's link between children's and animals' perceptions of temporality and a vision devoid of segmented temporality:

For human beings, time is very different. Not only are we aware of what has gone before, but we experience it as a weight that presses us down more and more. For this reason, we look with envy on the animals and on the small child who, like them, lives within the present moment, in a space protected by the 'fences of past and future.' (Small, 2010, p. 99)

Seen from this perspective, Gauri's departure to California may express her intention to undo the effects of historical cronos, by projecting self-preservation onto the neutral frame of the future. Therefore, her extreme gesture is a desperate expression of individualism/egoism, that privileges the integrity of the self at the expense of establishing/fostering other bonds. At the same time, I consider that Gauri is aware of the selfish nature of her actions and her withdrawal into solitude may also be regarded as an expression of remorse: 'Given what she'd done to Subhash and Bela, it felt wrong to seek the companionship of anyone else. Isolation offered its own form of companionship' (Lahiri, 2013, pp. 183-184). Moreover, from a Schopenhauerian perspective, Gauri's cling to isolation may reflect her attempt to transcend the illusory world of

\footnotetext{
${ }^{3}$ Upon Udayan's request, Gauri agreed to spy on a policeman and inform Udayan of his daily schedule. She was not aware that Udayan's fellows were planning the policeman's assasination and needed an pproximation of his daily routine.
} 
Maya/individuation by means of asceticism (Janaway, 2002, p. 122). I interpret the character's willful adherence to a reclusive life as a strategy of self-castigation and redemption. This attitude is aimed at destroying the selfish individuality by helping Gauri plunge into the timeless dimension of the world as thing in itself.

Gauri's attempted suicide during her temporary return to India also reflects her struggle with the sequential views of history. After an accidental encounter with Bela, Gauri is overwhelmed by her daughter's violent rejection and suddenly decides to fly to India. On the one hand, her visit to India indicates the idea of cycle, as Gauri's reconnects with the site of her departure, completing a full circle: from India to America and back. At the same time, her attempted suicide correlated with the notion of return, can be discussed in relation to Schopenhauer's notion of self-renunciation and Nietzsche's outlook on the eternal return:

She pressed herself against the railing of the balcony. It was high enough. She felt desperation rising up inside her. Also a clarity. An urge.

This was the place. This was the reason she'd come. The purpose of her return was to take her leave....

She closed her eyes. Her mind was blank. It held only the present moment [emphasis added], nothing else. The moment that, until now, she'd never been able to see [emphasis added]. She thought it would be like looking directly at the sun. But it did not deflect her.

Then one by one she released the things that fettered her. Lightening herself, the way she'd removed her bangles after Udayan was killed. What she'd seen from the terrace in Tollygunge. What she'd done to Bela. The image of a policeman passing beneath a window, holding his son by the hand. A final image: Udayan standing beside her on the balcony in North Calcutta. ...

She leaned forward. She saw the spot where she would fall. She recalled the thrill of meeting him, of being adored by him. The moment of losing him. The fury of learning how he'd implicated her. The ache of bringing Bela into the world, after he was gone. She opened her eyes. He was not there. (Lahiri, 2013, pp. 248-249)

Gauri's attempted suicide illustrates her intention to kill her individuality and transgress the world as Maya through death. According to Schopenhauer, death provides the cancellation of individuality, opening up the path to the timeless reality beyond appearances: 'Dying is the moment of that liberation from the one-sidedness of an individuality which does not constitute the innermost kernel of our true being, but is rather to be thought of as a kind of aberration thereof' (Schopenhauer, 1969, W2 p. 508). Considered from this perspective, Gauri's choice to end her life illustrates her 
determination to access circular time and erase the painful traces of linear history. Although she does not jump from the balcony, the fact that Gauri is finally able to perceive the present moment indicates her eventual capacity to confront the past and the future from the perspective of the gateway. Her urge to cross the ultimate border (between life and death) marks a brief yet healing passage into the realm beyond apparent plurality. Gauri's mental revision of her life illustrates her ability to revisit and understand the past from the perspective of the present moment. Along similar lines, Bela's subsequent letter that includes the promise of accepting Gauri as a grandmother indicates a sense of closure.

\section{Conclusion}

Gauri's layered transformation across physical and temporal borders suggests her adherence to values associated with Western modernity, such as autonomy, history as progress and individualism. The present analysis has aimed to demonstrate that Gauri's evolution foregrounds her ambivalent positioning between a teleological and a circular conception of history. On the one hand, Gauri's attachment to a linear conception of history seems aligned with the character's humanistic approach to self-redefinition as autonomous change. On the other hand, Gauri's humanistic reliance on reason and individualism is paralleled by her urge to dismantle traditional gender roles and define herself along disruptive, fragmented lines. From this perspective, the character aligns with postmodern, anti-foundational discourses of identity formation that contest the possibility of stable constructions. The end of the novel reveals the character's capacity to transgress the effects of a sequential view of history, by stepping into a circular version of time, that helps her reconcile with a version of the past filtered through the present.

Gauri's multifaceted approach to identity and change blends individualism, linear and circular time/history with an anti-foundational outlook that supports her radical change. These overlapping elements suggest that Lahiri has situated this character at the crossroads between modernist conceptions of cyclical time, modernity's celebration of reason and individualism and postmodern visions of fragmentation.

\section{References}

Anwar, N. (2015). Aestheticism, Postmodernism and Displacement in Jhumpa Lahiri's Fiction: A Novel View of the Search for Fulfillment by Obliviating the Past. Anchor Academic Publishing. 
Bandyopadhyay, D. (2009). Negotiating Borders of Culture: Jhumpa Lahiri's Fiction. Journal of Literature, Culture and Media Studies, 1(1), 97-108. http://www.ischolar.in/index.php/LLCMS/article/view/168676

Banerjee, B. (2010). Diaspora's 'Dark Room': Photography and the Vision of Loss in Jhumpa Lahiri's 'Hema and Kaushik.' The Journal of Commonwealth Literature, 45(3), 443-56. https://doi.org/10.1177/0021989410377393

Banerjee, S. (1984). India's Simmering Revolution. The Naxalite Uprising. Zed Books.

Bhalla, T.A. (2008). Between history and identity: Reading the authentic in South Asian diasporic literature. [Unpublished doctoral dissertation].

https://deepblue.lib.umich.edu/ bitstream/handle/2027.42/61737/?sequence=1

Brada-Williams, N. (2004). Reading Jhumpa Lahiri's 'Interpreter of Maladies' as a Short Story Cycle. MELUS, 29(3/4), 451-464. https://doi.org/10.2307/4141867

Bran, R.A. (2014). Immigration: 'A Lifelong Pregnancy? 'An Analysis of Jhumpa Lahiri's Fiction. [Unpublished doctoral dissertation]. https://eldorado.tudortmund.de/bitstream/2003/33621/1/Dissertation.pdf.

Brians, P. (2003). Modern South Asian Literature in English. Greenwood Press.

Bronner, E.S. (2011). Critical Theory. A Very Short Introduction. Oxford University Press. https://doi.org/10.1093/actrade/9780199730070.001.0001

Bottomore, T. (2003). The Frankfurt School and its Critics. Routledge. https://doi.org/10.4324/9780203407110

Butler, C. (2002). Postmodernism: A Very Short Introduction. Oxford University Press. https://doi.org/10.1093/actrade/9780192802392.001.0001

Caesar, J. (2005). American Spaces in the Fiction of Jhumpa Lahiri. English Studies in Canada, 31(1), 50-68. https://doi.org/10.1353/esc.2007.0002

Caesar, J. (2007). Gogol's Namesake: Identity and Relationships in Jhumpa Lahiri's The Namesake. Atenea, 27(1), 103-119.

Chetty, G.R. (2006). Versions of America: Reading American Literature for Identity and Difference. (Unpublished Master's thesis).

https://scholarsarchive.byu.edu/cgi/viewcontent.cgi?referer=\&httpsredir=1\&ar ticle $=1764 \&$ context $=$ etd

Cooper, M. (2006). Socialist humanism: A progressive politics for the twenty-first century. In G. Proctor, M. Cooper, P. Sanders \& B. Malcom (Eds.), Politicising the Person-Centered Approach: An Agenda for Social Change (pp.80-94). PCCS Books.

Dudley, W. (2009). Hegel and History. Sunny Press.

Iyer, S. (2009). Interpreter of Maladies: A Saga of Asian Immigrants. In M. F. Patel (Ed.), Recritiquing Women's Writing in English (Vol.1) (pp. 80-86). Sunrise Publishers \& Distributors. 
James, D. (2015). Worlded Localisms. Cosmopolitics Writ Small. In L. Platt, \& S. Upstone, (Eds.), Postmodern Literature and Race (pp. 47-61). Cambridge University Press. https://doi.org/10.1017/CB09781107337022.005

Janaway, C. (2002). Schopenhauer. A Very Short Introduction. Oxford University Press. https://doi.org/10.1093/actrade/9780192802590.001.0001

Jawaid, S. (1979). The Naxalite Movement in India. Associated Publishing Home.

Kammer, J. (2015, September 30). The Hart-Celler Immigration Act of 1965. Political figures and historic circumstances produced dramatic, unintended consequences. Center for Immigration Studies. https://cis.org/Report/HartCeller-Immigration-Act-1965

Kemper, B. (2011). The Language of Diaspora in Jhumpa Lahiri's Unaccustomed Earth. (Unpublished Master's thesis). https://engagedscholarship.csuohio.edu/etdarchive/528

Konzett, C.D. (2002). Ethnic Modernisms Anzia Yezierska, Zora Neale Hurston, Jean Rhys, and the Aesthetics of Dislocation. Palgrave Macmillan.

Lahiri, J. (2013). The Lowland. Alfred A. Knopf.

Madhurpana, M. (2006). Lahiri's Mrs. Sen's. The Explicator, 64(3), 193-196. https://doi.org/10.3200/EXPL.64.3.193-196

Maker, W. (2009). The End of History and the Nihilism of Becoming. In W. Dudley (Ed.), Hegel and History (pp.15-34). Sunny Press. https://doi.org/10.5840/hsaproceedings2009203

Munos, D. (2010). Diasporic Hereafters in Jhumpa Lahiri's Once in a Lifetime. In S. Schultermandl, \& S. Toplu (Eds.), A Fluid Sense of the Self. The Politics of Transnational Identity (pp. 139-157). LIT.

Murphy, W.J. (1989). Postmodern Social Analysis and Criticism, Contributions in Sociology, Number 79. Greenwood Press.

Mustafi, M.S. (2012, July 11). Naxalbari: The Cradle of India's Bloody Class War. The New York Times. https://india.blogs.nytimes.com/2012/07/11/naxalbari-the-cradleof-indias-bloody-class-war

Nabholz, A.C. (2007). The Crisis of Modernity: Culture, Nature, and the Modernist Yearning for Authenticity. [Unpublished doctoral dissertation]. https://edoc.unibas.ch/639/1/DissB 7969.pdf

Norman, R. (2004). On Humanism. Thinking in Action. Routledge. https://doi.org/10.4324/9780203219911

Olsen, L. (1990). Circus of the Mind in Motion Postmodernism and the Cosmic Vision. Wayne State University Press.

O’Malley, S. (2014). Making History New. Modernism and Historical Narrative. Oxford University Press.

https://doi.org/10.1093/acprof:oso/9780199364237.001.0001 
Raj, J.S. \& Jose, S. (2014). Diasporic Ambivalence in Jhumpa Lahiri's The Namesake. In B. Singh (Ed.), Indian Writing in English: Critical Insights (pp. 26-37). Authorspress.

Saha, A.S. (2009). The Problem of Personal Identity: A Philosophical Survey through the Selected Fictions of Anita Desai, Bharati Mukherjee, Sunetra Gupta, and Jhumpa Lahiri in the Context of the Indian Diaspora. Humanicus 3, 60-74.

Samanta, S. (2014). Jhumpa Lahiri's The Lowland: A Family Saga with a Political Perspective. Galaxy: International Multidisciplinary Research Journal, 3(IV), 110116. https://papers.ssrn.com/sol3/papers.cfm?abstract id=2760706

Schopenhauer, A. (1969). The World as Will and Representation vols.1,2 (E. F. J. Payne, Trans.). Dover Publications, Inc.

Seshagiri, U. (2016, February 15). Jhumpa Lahiri's Modernist Turn [Review of the book The Lowland, by J. Lahiri]. Public Books. http://www.publicbooks.org/jhumpalahiris-modernist-turn/

Song, M.H. (2007). The Children of 1965: Allegory, Postmodernism, and Jhumpa Lahiri's The Namesake. Twentieth-Century Literature 53(3), 345-370. https://doi.org/10.1215/0041462X-2007-4001

Small, R. (2010). Time and Becoming in Nietzsche's Thought. Continuum International Publishing Group.

Stoican, A. E. (2018). Diffused Gender Codes and Transcultural Outcomes in Jhumpa Lahiri's The Lowland. In A. Zamfira, C. de Montlibert, D. Radu, (Eds.), Gender in Focus (pp.160-177). Barbara Budrich. https://doi.org/10.2307/j.ctvddzn5f.10

Williams, A. L. (2007). Foodways and Subjectivities in Jhumpa Lahiri's "Interpreter of Maladies". MELUS, 32(4), 69-79. https://doi.org/10.1093/melus/32.4.69

Williams, L. B. (2002). Modernism and the Ideology of History. Cambridge University Press. https://doi.org/10.1017/CB09780511485350

William, M. (2016). The Genesis of Political Correctness. The Basis of a False Morality. CreateSpace Independent Publishing Platform.

Zhang, Y. (2012). Asian American Forms: From Realism to Modernism. (Unpublished doctoral dissertation). University of Washington https://digital.lib.washington.edu/researchworks/bitstream/handle/1773/202 17/Zhang washington 0250E 10110.pdf?sequence=1

Zimmer, H. (1990). Myths and Symbols in Indian Art and Civilization. Motilal Banarsidass.

Reviewers:

1. Tadd Graham Fernée, PhD, New Bulgarian University

2. Anonymous
Handling Editor:

Stan Bogdanov, PhD

New Bulgarian University 